\title{
Variations on the larval incubation of Anodontites trapesialis (Unionoida, Mycetopodidae): Synergetic effect of the environmental factors and host availability
}

\author{
Callil, CT. ${ }^{a^{*}}$, Krinski, D. ${ }^{b}$ and Silva, FA. ${ }^{c}$ \\ aDepartamento de Biologia e Zoologia, Instituto de Biosciências, Universidade Federal de Mato Grosso - UFMT, \\ Av. Fernando Corrêa da Costa, 2367, Boa Esperança, CEP 78060-900, Cuiabá, MT, Brazil

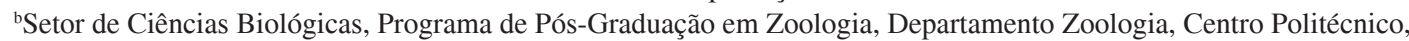 \\ Universidade Federal do Paraná - UFPR, Jardim das Américas, CP 19020, CEP 81531-980, Curitiba, PR, Brazil \\ 'Programa de Pós-Graduação em Ecologia e Conservação da Biodiversidade, \\ Instituto de Biosciências, Universidade Federal de Mato Grosso - UFMT, \\ Av. Fernando Corrêa da Costa, 2367, Boa Esperança, CEP 78060-900, Cuiabá, MT, Brazil \\ *e-mail: callil@ufmt.br \\ Received February 16, 2011 - Accepted January 25, 2012 - Distributed August 31, 2012
}

(With 3 figures)

\begin{abstract}
The unionid Anodontites trapesilais (Lamarck, 1819) like most freshwater mussels is a parasite of fish. So it is trivial to assume that the availability of hosts is an important factor for the maintenance of unionoid populations. What seems obvious is not always so easy to demonstrate. This study proposes to investigate the effects of abiotic and biotic variables related to the incubation of larvae in A. trapesialis. For this, we estimate different biological indexes and try to capture the dimensionality of the fish, along with the temporal variation of environmental variables. From the application of a CCA, it was demonstrated that there was a synchronicity among the factors and variables proposed here, and we infer that the flood pulse acts as a synergistic factor in this process.
\end{abstract}

Keywords: reproduction, freshwater mussels, fishes, host relationship, wetlands.

\section{Variações na incubação larval de Anodontites trapesialis (Lamarck, 1819) \\ (Bivalvia Unionoida, Mycetopodidae): efeito sinergético de fatores ambientais e disponibilidade de hospedeiros}

\begin{abstract}
Resumo
O bivalve Anodontites trapesilais (Lamarck, 1819), como a maioria dos mexilhões de água doce, é parasita de peixes. Então, seria trivial supor que a disponibilidade de hospedeiros é um fator importante para a manutenção das populações dos unionoideos. Porém, o que parece óbvio nem sempre é tão simples de ser demonstrado. Este estudo se propõe a investigar os efeitos de variáveis abióticas e bióticas relacionadas com a incubação de larvas de A. trapesialis. Para tanto, nós estimamos diferentes Índices Biológicos e tentamos capturar a dimensionalidade da comunidade de peixes juntamente com a variação temporal das variáveis ambientais. A partir da aplicação de uma CCA, demonstramos que há uma sincronicidade entre os fatores e as variáveis aqui propostas, e inferimos que o pulso de inundação atua como fator sinergético desse processo.
\end{abstract}

Palavras-chave: reprodução, bivalves de água doce, peixes, relação parasito-hospedeiro, áreas umidas. 


\section{Introdution}

Unionoida mussels have a complex life cycle. After fertilization, the early stages of development occur in the inner demibranch (Bonetto and Ezcurra, 1962; 1965). The planktonic larvae, called glochidium or lasidium, complete their development cycle as temporary parasites of fish (Fryer, 1970, Mansur et al., 1987). Around 27 days after fixation, they complete metamorphosis and unfasten themselves from the fish and become a benthic organism (Bonetto and Ezcurra, 1962; Castellanos and Landoni, 1990).

Some limiting factors such as temperature (Bauer, 2000; Strayer, 2008; Oliveira et al. 2010), food availability and parasite-host interaction, influences directly in the reproductive dynamics of these mussels (Haag and Warren-Junior, 1997; Avelar and Mendonça, 1998; Beasley et al., 2000). To know which environmental factors are most important to each one of the reproduction attributes will depend on the combined effect provided by the environment in which these bivalves occur (Galbraith and Vaughn, 2009). Few studies have examined the environmental influences in the reproductive dynamics of the population and information is unknown related to the incubation period, elimination of larvae and parasite-host interaction for neotropical species.

Anodontites trapesialis (Lamarck, 1819) (Unionoida, Mycetopodidae) is widely geographically distributed and may represent the highest percentage of benthic biomass in rivers, lakes and flood plains (Colle and Callil, 2012). Although on the national list of endangered species, (Brasil, 2004), this species can be found in abundance in farm ponds and fish farming (Guardia-Felipi and Silva-Souza, 2008) and has been considered a species for cultivation and potential source of protein (Tello-Panduro et al., 2003). However being sedentary and excellent filter feeders it has been used as a sentinel organism (Callil, 2003) for studies of environmental monitoring and an effective biomarker of pesticides (Lopes et al., 1992) and heavy metals like mercury (Callil and Junk 1999, 2000), lead and cadmium (Tomazelli et al., 2003).

In order to understand the processes related to the larval development and completion of hatching process, we intend is to answer: i) If biometrics Indexes vary between incubated and non-incubated individuals? ii) Is there a relation between frequency of the individuals incubated with richness and abundance of fish? iii) Is the Incubation is influenced by limnological variables or the presence of hosts? These questions were elaborated on the assumption that environmental factors are subject to changes resulting from the periodic flood pulse, inherent in the Pantanal, and these influencing reproduction and host availability. The assessment and thread of this premise is the object of this study.

\section{Material and Methods}

\subsection{Sampling design}

Samples of mussels were collected in an artificial ponds, which acts as shallow lake (16 '32 $29^{\circ}, 0^{\prime}$ ' $\mathrm{S}$ and $56^{\circ} 26^{\prime} 16,5^{\prime}$ ' WO) under Indirect Influences of the floodplain of the Cuiabá Rivernear to RPPN SESC Pantanal. Every month during November 2006 to October 2007, the mussels were collected touching the substrate by hand and feet. Over every sampling event depth and transparency were measured with a Secchi disk and temperature $\left({ }^{\circ} \mathrm{C}\right)$, $\mathrm{pH}$, dissolved oxygen (OD mg. $\mathrm{L}^{-1}$ ) using a multi probe.

For all collected specimens $(\mathrm{n}=180 ; 15$ per month), height $(\mathrm{H}, \mathrm{mm})$, total length ( $\mathrm{Lt}, \mathrm{mm})$, demibranch length (Ltd, $\mathrm{mm}$ ) were obtained with a digital caliper. The measures related to the mass as total weight (Wt, g), weight of soft parts (Wb, g), shell weight (Ws, g) (Callil and Mansur, 2007) and weight of demibranch (Wd, g) were obtained with an analytical balance. All individuals had their demibranches examined under the microscope to detect the presence of eggs and larvae. These material can be found at the Invertebrate Aquatic Collection of UFMT - CIAMT under the following numbers: CIAMT 593, CIAMT, CIAMT 595, CIAMT 596, CIAMT 597, CIAMT 598, CIAMT 599, CIAMT 600, CIAMT 601, CIAMT 602, CIAMT 603 and CIAMT 604.

Data on the composition of local fish fauna were collected together with the capture of the bivalves. For this, we used two cast nets (of $3 \mathrm{~m}$ and $2 \mathrm{~cm}$ between nodes) and a trawl net $(20 \times 4 \mathrm{~m}$ with $1 \mathrm{~cm}$ between nodes $)$. The cast nets were launched 100 times in each sampling and the trawl net twice. All specimens were identified using the literature (Britski et al., 2007; Buckup et al., 2007). After data collection, in order to verify the presence of larvae (lasidia) of A. trapesialis, we examined by the naked eye and stereoscopic microscope, the body surface, fins and gills of all fishes collected. The richness, relative and total abundance for samples of fish were determined.

\subsection{Analytical design}

With the biometric variables, the possible differences among incubated and non-incubated individuals were investigated by ANOVA (significance level of 5\%). From length and weight variables, three biological indexes were estimated: Condition Index (CI), Condition Somatic Index (SCI) and Incubation Index (ICI). For this, the allometric method was used for selection, the results of which are not subject to distortions due to the variation in length of individuals, and which allows comparison of samples formed by individuals of different sizes (Braga, 1986; LimaJunior et al., 2002). These biological indexes were calculated for each individual from the expression: $\mathrm{CI}=1000\left(\mathrm{Wt} / \mathrm{Lt}^{\mathrm{b}}\right)$, $\mathrm{SCI}=1000\left(\mathrm{~Wb} / \mathrm{Lt}^{\mathrm{b}}\right)$ and $\mathrm{ICI}=1000\left(\mathrm{Wd} / \mathrm{Ld}^{\mathrm{b}}\right)$. To calculate the coefficient ${ }^{\mathrm{b}}$, total sample was used for adjusting the expression of weight $\mathrm{x}$ length $\left(\mathrm{W}=\mathrm{aL}^{\mathrm{b}}\right)$, using the least squares method applied to the data converted to their natural logarithms (Lima-Junior et al., 2002).

The differences between the indexes (CI, CSI and ICI) of the incubated and non-incubated specimens were tested by analysis of variance (ANOVA). A simple linear regression was used among the incubated A. trapesialis and richness and abundance of fishes captured during the sampled period. 
The influence of environmental characteristics on the abundance and richness of fish, biological indices and frequency of incubated and non-incubated was observed using a canonical correspondence analysis (CCA). We first ran a correspondence analysis using SYSTAT 13, at function smart correspondence analyses with canonical standardization, that uses a multiway frequency (environmental variables, the index and the incubated and non-incubated frequency) table format with the first column indicating row labels (months) on the response matrix to obtain an estimate of total inertia or variation explained in the matrix.

\section{Results}

\subsection{Limnological characteristics of Baía do Meio Lake}

During the sampled period the water though warm, as well as oxygenated (8.50 to $\left.10.10 \mathrm{mg} . \mathrm{L}^{-1}\right)$, remained neutral (6.37 to 7.46). The temperature oscillated from 23 to $32.30{ }^{\circ} \mathrm{C}$, and the largest variation was detected for the depth that was 95 to $168 \mathrm{~cm}$ and for transparency ranging from 23 to $110 \mathrm{~cm}$.

\subsection{Biometry $x$ incubation}

Were sampled 180 individuals that varied from 58 to $210 \mathrm{~mm}$ in length and 9 to $330 \mathrm{~g}$ in weight. The monthly average value of body weight was 52.24 to $125.93 \mathrm{~g}$ and the Incubation Index from 1.364 (March) to 3.159 (August). The linear regression was significant for the relationships between the Lt $x \operatorname{Ld}\left(\mathrm{p}<0.001 ; \mathrm{r}^{2}=0.605\right)$ and the $\operatorname{Ld} \mathrm{x}$ Ldi $\left(\mathrm{p}<0.001 ; \mathrm{r}^{2}=0.671\right)$ but the Ld xWd $(\mathrm{p}<0.001$; $\left.r^{2}=0.320\right)$ and Ldi $x$ Wd $\left(p<0.001 ; r^{2}=0.302\right)$, but although it was statistically significant, the correlation coefficient was low.

The larval incubation of $A$. trapesialis always occurred on the central part of inner demibranch, characterised by intumescences of the gill filaments of a whiteish colour. During the sampled period, larvae were observed in the inner demibranch in $71 \%$ of the mussels $(n=127$ incubated) of which the monthly variation of the relative frequency of incubated ranged from 13 to $93 \%$ (Figure 1). The total length classes (Lt) varied from 60 and $185 \mathrm{~mm}$ for all specimens and from 115 to $185 \mathrm{~mm}$ for the incubated ones. The total weight classes (Wt) varied from 20 to $340 \mathrm{~g}$ for all specimens, and from 80 to $340 \mathrm{~g}$ for the incubated ones. It has been noted that the smaller specimens found in the classes of Lt of 55 to $110 \mathrm{~mm}$ and Wt 10 to $70 \mathrm{~g}$ were not incubating larvae. When comparing the non-incubated and incubated individuals, the biometric variables were different for to $\mathrm{Lt}\left(\mathrm{p}=0.046 ; \mathrm{F}_{1,178}=4.055\right), \mathrm{Wt}(\mathrm{p}=0.05$; $\left.\mathrm{F}_{1,178}=3.617\right)$, Wd $\left(\mathrm{p}<0.001 ; \mathrm{F}_{1,178}=49.661\right)$, and Ld $\left(\mathrm{p}=0.019 ; \mathrm{F}_{1,178}=5.560\right)$. The $\mathrm{Wb}\left(\mathrm{p}=0.13 ; \mathrm{F}_{1,178}=2.243\right)$ and $\mathrm{h}\left(\mathrm{p}=0.27 ; \mathrm{F}_{1,178}=1.209\right)$ were not different.

\subsection{Biological indexes $x$ incubation}

The equations of the length $\mathrm{x}$ weight relationship adjusted to obtain the $\mathrm{b}$ coefficient for each index are the following: $\mathrm{Wt}=0.0001 \mathrm{Lt}^{2.551}$ for Condition Index (CI), $\mathrm{Wb}=0.0001 \mathrm{Lt}^{2.7848}$ for Somatic Condition Index (SCI) and $\mathrm{Wd}=0.002 \mathrm{Ld}^{1.6257}$ for Incubation Index (ICI). The ranges of variation were $\mathrm{CI}$ : 0.071 to 0.282 ; SCI: 0.052 to 0.186 and ICI: 0.616 to 4.815 .

The CI ( df $=178, \mathrm{~F}=3.182, \mathrm{P}=0.076)$ and $\mathrm{SCI}(\mathrm{df}=178$, $\mathrm{F}=1.270 \mathrm{P}=0.261$ ) did not show differences among incubated and non-incubated, but when considering the Incubation Index, as expected (Figure 2), significant differences (ICI: $\mathrm{df}=178, \mathrm{~F}=51.804 \mathrm{P}<0.001$ ) were shown.

\subsection{Fish fauna}

1733 individuals were sampled in the Baía do Meio distributed among 61 species, five orders and 14 families. Among the five orders found, the one that showed greater wealth of species was the Characiformes (32 species), followed by the Siluriformes ( 19 species), the Perciformes (7 species), the Gymnotiformes (2 species), and one species of the Cyprinodontiformes. The most abundant family was the Characidae (Characinae) with 358 individuals, followed by the Curimatidae with 329. The least abundant families were the Characidae (Cheirodontinae), the Characidae (Iguanodectinae), the Hypopomidae, the Sternopygidae, and the Poeciliidae, with only one individual.

\subsection{Environmental factors $x$ fish fauna $x$ incubation}

The canonical correspondence analysis explained $93.32 \%$ of the total variation data represented by the temporal gradient. The first axis accounted for $84.73 \%$ of the variation explained mainly by abundance and transparency, while the second axis represented $8.58 \%$ variation. All axes from CCA (sum of all eigenvalues - Total Inertia $=0.219, \mathrm{c}^{2}=1198.614, \mathrm{df}=121, \mathrm{P}=0.0001$ ) were significant in this analysis. Figure 3 shows that incubation is often associated with dry season months (July, August and September), and that richness and abundance of fish are associated with October, November and December, months of flooding. On the other hand, the frequency of non-incubated individuals is related to the months of the rainy season (January, February and March) along with depth and transparency.

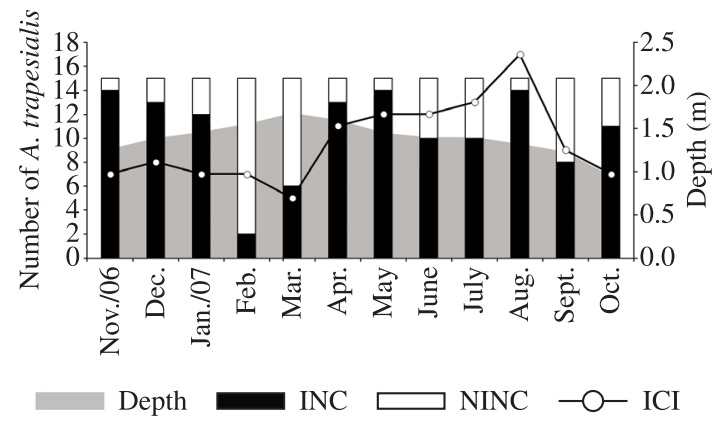

Figure 1. Temporal variation of depth $(\mathrm{cm})$ incubated (I) and non-incubated (NI) and Incubation Index (ICI) over the sampled period in the Baía do Meio lake in the Pantanal of Poconé, Mato Grosso state. 


\section{Discussion}

The Baía do Meio Lake is an artificial habitat that has been undergoing the water regime conditions of the Pantanal over the past ten years. Artificial environments contribute to the degradation of the Unionoida, because they restrict their distribution and can retain isolated populations. However, the environment is housed in an area subject to periodic flood pulse, characteristic of the Pantanal. Maintaining the connection with the floodplain adjacent to the rivers makes possible the dispersal of the bivalves' larvae.

During the whole sampled period, incubated individuals were found with more frequency during November, May, and August; agreeing with Callil and Mansur (2007) who observed A. trapesialis incubated in April and May in the Pantanal. Bonetto and Ezcurra (1962) also found A. trapesialis forbesianus (Lea, 1860) in Argentin, incubated between August and December. In the gametogenesis and larval morphology study of Popenaias popeii (Lea, 1857) the species shows a short period of incubation and a long period of release of gametes, that makes it considered to be an asynchronous reproducer (Smith et al., 2003). The synchrony of the reproductive cycle maybe a specific characteristic of each population, or it may vary in populations that occur in different geographical areas (Eversole, 1989). The Unionidae Anodonta Lamarck, 1799 have multiple reproductive peaks in a single period (Heard, 1975) and Glebula rotundata (Lamarck, 1819) also has a cycle of up to three reproductive periods (Parker et al., 1984). As to the reproductive aspects of the A. trapesialis (Lamarck, 1819) (Unionoida) studied on the Pantanal region of the state of Mato Grosso by Callil and Mansur (2007), it is possible to say that the gametogenesis is continuous, however, with trends to the gonadal maturation stage (Silva-Souza et al., 2011). Ovogenesis has its maximum maturation period in April and May, whereas spermatogenesis from April to July. Gametogenesis is continuous with maturation peaks and elimination of gametes during the dry season. In this study, a continuity of specimens with larvae and/or eggs was observed in the demibranch over the sampling period. In the months of November of 2006, and May and August of 2007, there was a higher relative frequency of incubated specimens, also demonstrated by CCA. When this period is compared with Callil and Mansur's (2007) dates, conformity is noted related to the period in which there is the presence of embryos at the gills (April and May). Furthermore, the period with higher frequency of incubated species found in this work occurs at the onset of the dry season, when water leaves the flood plains and returns to the main channels (May) and in the dry season (August to November), also noted by Callil and Mansur (2007). In this, a relation can be traced between this period of higher maturation and elimination of gametes with the exit of fish from the lakes and flooding of adjacent areas, which are characteristic of the studied region. Thus, it is possible to associate the relation of dependence of the bivalves with the fish fauna.
From the environmental variables considered in this study, depth and transparency seem to have a negative relationship with the reproduction of the bivalves. The variation of the water depth refers to the fluctuation of the water level of the studied site, and this characteristic associated with the load of suspended solids seems to influence the reproductive period of freshwater bivalves (Beasley et al., 2000), mainly in tropical regions where the water temperature is constant. The hydroperiod, marked for

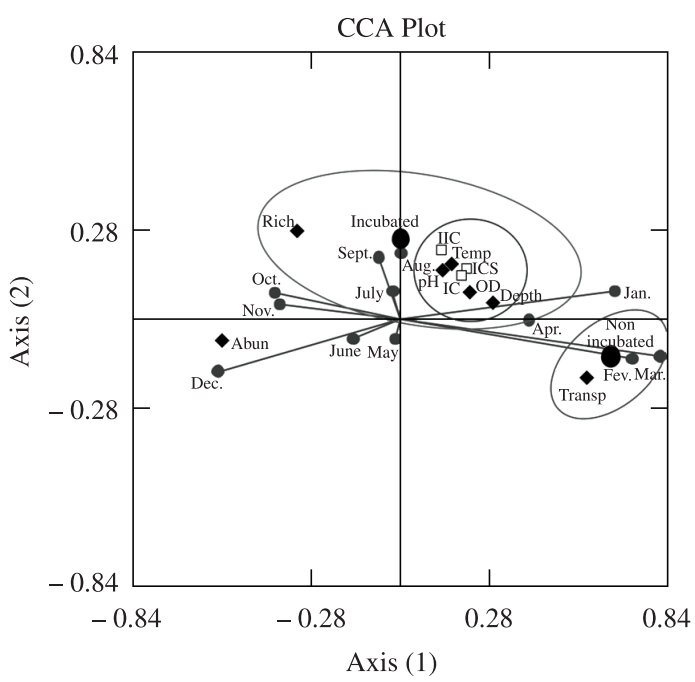

Figure 2. Canonical correspondence analysis (CCA) biplot of the first two axes showing the relationship between Frequency of Incubation (INC, NINC, • ); Index (IC, ICS, IIC, $\square$ ); environmental variables (Rich, Abund, $\mathrm{pH}, \mathrm{OD}$, Temp, Depth, Transp, $\downarrow)$ and temporal variations - months (arrows).

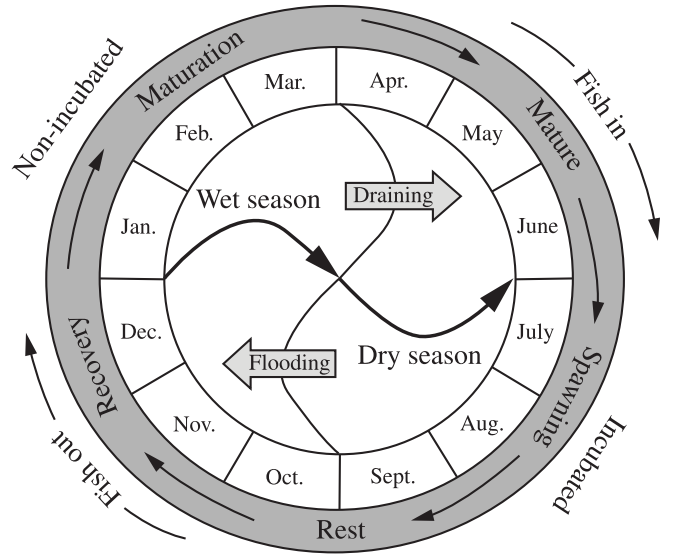

Figure 3. The floodpulse-driven wet-and-dry cycle in the Pantanal giving the synergistic effect of abiotic and biotic factors demonstrated by the synchronicity of reproduction in freshwater mussels with basic patterns of fish migration. Adapted from Wantzen et al. (2008). 
a seasonal flood pulse in the Pantanal (Junk et al., 1989; Junk and Cunha 2005), makes it possible for the lakes to receive a higher amount of organic matter consequently increasing the amount of food available for those bivalves. The favourable conditions with great availability of food promote an increment of energy reflected by the Condition Index. This energy increase will later be transferred from the digestive glandules to the gonads, thus the amount and quality of available food, as an intrinsic factor, is also capable of controlling reproduction (Grotta and Lunetta,1980).

Regarding A. trapesilais, larval incubation has been noted on the central part of the inner demibranch for all the analysed specimens, and the characteristics of the incubated demibranch were intumescence and whiteish in colour, as noted in other species for this genus (Bonetto and Ezcurra, 1962; Maldonado et al., 1990). It has been noted that the demibranches of $P$. popeii destined for the marsupial function differ from the outer demibranch by presenting a modified septum (Smith et al., 2003), a condition also described for A. trapesialis by Callil (2003). Yeager and Neves (1986) researched the Quadrula cylindrical (Say, 1817), and noticed that $65 \%$ of the incubated females kept larvae only on the outer demibranch, and $35 \%$ used all four. According to Ituarte (1984), the behaviour of incubating eggs and larvae on specific spots of the demibranch may be related to the protection and the development of the offspring as a reaction to the biotic and abiotic characteristics of the freshwater environments.

As to the biometry of $A$. trapesialis, it has been noted that there is significant relation between the length of the demibranch and the total length of the shell demonstrating that the longer the length is, the longer the spot used for incubating the eggs and/or larvae will be. For Sphaerium striatinum (Sphaeriidae), a diminute bivalve that incubates the eggs that exhibit development without the larval planktonic stage, do not show a significant relation between the length of the bivalve and the length of the larval development region they have nevertheless, at the moment of the maturation peak, it could be predicted that the size of the spot used for the maturation increases due to the total length (Beekey and Hornbach, 2004). This inference can be confirmed by McIvor and Aldridge's (2007) study on reproductive biology of Pseudanodonta complanata (Rossmõssler, 1835) (Unionidae), in which it was noted that the number of incubated glochids increases due to the total length of the bivalve (Figure 3).

The larvae of most unionoids are parasitic on fishes, so it is reasonable to suspect that the distribution and abundance of host fish might be an important factor in limiting the unionoid population (Strayer, 2008). A. trapesialis fits into this scenario characterised as a temporary parasite (Bonetto and Ezcurra, 1962) and most often forms a cyst on the tissue, which does not cause severe lesion to the hosts (Silva-Souza and Eiras, 2002). This relation was described by Arey (1932) and Murphy (1942) as a nutrition relation between the larvae and the degeneration of the host tissue, which is the source of nutrients during metamorphosis. There is a wide gap of information regarding the host- parasite relationship in unioniods: almost nothing is known about the infection of fish and the parasite-host relation in the Neotropical region (Silva-Souza and Eiras, 2002; Callil and Mansur, 2007) and little is available with this approach in the world (Hoggarth, 1992; Strayer, 2008).

Biological Indexes are much used in studies on oysters widely grown for commercial purposes, due to the fact that they reflect the period of sexual maturation as well as the nutritional conditions (Absher and Christo, 1993), and they are also applied to biomonitoring (Callil, 2003; Rebelo et al., 2005). The Condition Index reflects changes in the animal's physiology, especially during larvae incubation, and has also been broadly used to estimate mean weight from a known length and to calculate the index of physical condition of populations (Albuquerque et al., 2009). It would be obvious that the CI and SCI were directly associated with the gonadal maturation period (Aswani and Hamilton, 2004) and therefore would be expected to be closely related to larval hatching and/or nutritional value of the bivalve, however the results of this study did not show differences for the CI and SCI among incubated and not incubated mussels. Abujanra et al. (2009) considering that difficulties such as the strong correlation between the input parameters ( $a$ and $b$ of the length-weight relationship), the existence of allometry in the growth of many species (Braga, 1986), and the limitations in comparing different populations are some controversial points regarding the use of condition factors. However, the Biological indexes may be affected by a wide range of factors, such as temperature, the gametogenic cycle of the species as well as the availability of food, for these last two are the most influential ones (Orban et al., 2002). Stressing conditions or environmental situations that require greater energy expenditure (release of gametes, for instance) may be responsible for the low condition indexes observed in certain periods of the year.

The factors that exert greater influence on the bivalves' condition are the availability of food, temperature, and salinity (Hickman and Illingworth, 1980; Smaal and Van Stralen, 1990). During this investigation it has been noted that limnological variables are related to the Indexes (CI, SCI and ICI) (Figure 2). These factors may be considered an important exogenous factor for the control of the reproduction of the Unionoida bivalves (Jones et al., 1986; Avelar and Mendonça, 1998; Beasley et al., 2000). It is known that temperature influences gametogenesis, incubation, and of larval development of larvae in temperate regions (Araujo and Ramos, 2000). Still, the regulation of gametogenesis and larval incubation is not restricted to a single factor. Haag and Warren-Junior (2003) analysed the behaviour of larval release of seven species of freshwater bivalve family Unionidae, and the results showed that the physical interaction with fish is necessary for the stimulation of large releases of larvae. Although we did not identify the long-awaited statistical significance between the composition of icitiofauna with factors that reflect incubation, this study demonstrated that there is, rather, 
a relation between wealth and abundance of fish with the frequency of incubated bivalves.

Summarising, the weight (Wd) and the length of the demibranch (Ldi) have shown significant differences between the incubated and non-incubated specimens. There is a relationship among environmental variables and the Biological Indexes (CI, SCI and ICI). The fish fauna composition seems to be synchronised with the number of incubated A. trapesialis. These statements lead us to suggest that there is a synergism between endogenous and exogenous factors in relation to the reproduction of freshwater bivalves. The knowledge on the parasite-host relation as well as on the unionoides reproductive aspects is a way of contributing to the preservation of the species. The fish dependence on completing the metamorphosis up to the juvenile stage increases its susceptibility to any environmental disturbance, since the decline in the abundance of fish, the introduction of exotic fish or changes to the groups of fish may provoke drastic consequences to the ability of the bivalves for having success in their reproduction (Kneeland and Rhymer, 2007).

Among the 115 species (underestimated) freshwater mussels recorded in Brazil, 26 (11 Hyriidae and 15 Mycetopodidae) are in the red list of threatened species (Brasil, 2008), in the EUA and in Canada 300 species and subspecies of Unionoida, about $72 \%$ are threatened (Vaughn and Hakenkamp, 2001). This group is considered to be endangered due to the frailty of the riparian sites, which are subjected to anthropic actions. Research on gametogenesis, incubation period, and the relations established between these bivalves with their hosts are scarce in Brazil, mostly when it comes to the Pantanal region, which has a characteristic flood pulse. Among various factors, knowledge on the reproductive cycle is essential for decision making about the sustainable management of this group.

Acknowledgements - The authors thank CNPq/PELD site Pantanal North, process number 132194/2006-6, the Programa de Pós-graduação em Ecologia e Conservação da Biodiversidade - UFMT and SESC-Pantanal for support. We are also grateful to colleagues at the Laboratory of Aquatic Ecology- NEPA and those who were involved in this work, directly or indirectly. We thank Dr. Angela Teresa Silva Souza and Dr. Roberto Silveira for reading the manuscript and making good suggestions.

\section{References}

ABUJANRA, F., AGOSTINHO, AA. and HAHN, NS., 2009. Effects of the flood regime on the body condition of fish of different trophic guilds in the Upper Paraná River floodplain, Brazil. Brazilian Journal of Biology, vol. 69, no. 2, p. 459-468. http://dx.doi.org/10.1590/S1519-69842009000300003

ABSHER, TM. and CHRISTO, SW., 1993. Índice de Condição de ostras da região entre - marés da Baía de Paranaguá, Paraná, Brasil. Archives of Biology and Technology, vol. 36, no. 2, p. 253-261.

ALBUQUERQUE, FS., PESO-AGUIAR, MC., ASSUNCAO-ALBUQUERQUE, MJT. and GALVEZ, L., 2009. Do climate variables and human density affect Achatina fulica (Bowditch) (Gastropoda: Pulmonata) shell length, total weight and condition factor? Brazolian Journal of Biology, vol. 69, no. 3, p. 879-885. http://dx.doi.org/10.1590/S1519-69842009000400016

ARAUJO, R. and RAMOS, MA., 2000. Status and conservation of the relict giant European freshwater pearl mussel Margaritifera auricularia (Spengler, 1793). Biology Conservation, vol. 96, p. 233-239. http://dx.doi.org/10.1016/S0006-3207(00)00075-6

AREY, LB., 1932. The formation and structure of the glochidial cyst. The Biological Bulletin, vol. 62, p. 212-221. http://dx.doi. org/10.2307/1537553

ASWANI, S. and HAMILTON, RJ., 2004. Integrating indigenous ecological knowledge and customary sea tenure with marine and social science for conservation of bumphead parrotfish (Bolbometopon muricatum) in the Roviana Lake, Solomon Islands. Cambridge. Environmental Conservation, vol. 31, p. 69-83. http:// dx.doi.org/10.1017/S037689290400116X

AVELAR, W. and MENDONÇA, S., 1998. Aspects of gametogenesis of Diplodon rotundus gratus (Wagner 1827) (Bivalvia: Hyriidae) in Brazil. American Malacological Buletin, vol. 14, p. 157-63.

BAUER, G., 2000. Life-history variation on different taxonomic level of Naiads. In BAUER G. and WACHTLER, K. (Eds.). Ecology and Evolution of the Freshwater Mussels Unionoida. Ecological Studies. vol. 145, p. 83-91. http://dx.doi.org/10.1007/978-3-64256869-5_5

BEASLEY, CR., TURY, E., VALE, WG. and TAGLIARO, CH., 2000. Reproductive cycle, management and conservation of Paxyodon syrmatophorus (Bivalvia:Hyriidae) from the Tocantis River, Brazil. Journal of Molluscan Studies, vol. 66, p. 393-402. http://dx.doi.org/10.1093/mollus/66.3.393

BEEKEY, BMA. and HORNBACH, DJ., 2004. The effect of size-limited brood capacity on brood size in a freshwater bivalve. American Midland Naturalist, vol. 151, no. 2, p. 274-285. http:// dx.doi.org/10.1674/0003-0031(2004)151[0274:TEOSBC]2.0.CO;2

BONETTO, AA. and EZCURRA, ID., 1962. El desarrollo del lasidium de Anodontites trapesialis forbesianus (Lea) (Mollusca, Lamellibranchiata). Buenos Aires. Physis, vol. 23, no. 65, p. 195-203.

-, 1965. Notas Malacologicas III. 5) La Estructura del periostraco en el género Anodontites 6) El lasidium de A.trapezeus (Spix), 7) El lasidium de Mycetopoda siliquosa Spix. Physis, vol. 25, no. 69, p.197-204.

BRAGA, FMS., 1986. Estudo entre fator de condição e relação peso / comprimento para alguns peixes marinhos. Revista Brasileira de Biologia $=$ Brazilian Journal of Biology, v. 46, n. 2, p.339-346.

Brasil. Ministério do Meio Ambiente - MMA, 2004. Instrução normativa $\mathrm{n}^{\circ} 5$, de 21 de maio de 2004. Anexo I - Lista nacional das espécies de invertebrados aquáticos e peixes ameaçadas de extinção. Diário Oficial da República Federativa do Brasil, Brasília DF, 28 maio 2004. Available from: <http://www.ibama. gov.br/pndpa/legislacao.php?id_arq=123>. Acess in: 23 set. 2009.

Brasil. Ministério do Meio Ambiente - MMA, 2008. Livro vermelho da fauna brasileira ameaçada de extinção. Brasília: MMA; Belo Horizonte: Fundação Biodiversitas. vol. 1.

BRITSKI, HA., SILIMON, KS. and LOPES, BS., 2007. Peixes do Pantanal: manual de identificação. Brasília: Embrapa. 230 p.

BUCKUP, PA., MENEZES, NA. and GHAZZI, MS., 2007. Catálogo das espécies de peixes de água doce do Brasil. Rio de Janeiro: Museu Nacional. 195 p. 
CALLIL, CT., 2003. Base de dados direcionada a elaboração de um programa de monitoramento de águas continentais utilizando moluscos bivalves. Porto Alegre: Biociências, Pontifícea Universidade Católica do Rio Grande do sul. 227 p. Tese de Doutorado em Ciências Biológicas.

CALLIL, CT. and JUNK, WJ., 1999. Concentração e incorporação de mercúrio por moluscos bivalves Anodotites trapesialis (Lamarck, 1819) e Castalia ambigua (Lamarck, 1819) do Pantanal de Poconé - MT, Brasil. Biociências, vol. 7, no. 2, p.3-28.

-, 2000. Aquatic gastropods as mercury indicators in the Pantanal of Poconé region (Mato Grosso, Brasil). Water, Air and Soil Pollution, vol. 319, p. 319-330.

CALLIL, CT. and MANSUR, MCD., 2007. Gametogênese e dinâmica da reprodução de Anodontites trapesialis (Lamarck) (Unionoida;Mycetopodidae) no lago Baía do Poço, planície de inundação do rio Cuiabá, Mato Grosso, Brasil. Revista Brasileira de Zoologia, vol. 24, no. 3, p. 825-840.

CASTELLANOS, ZA. and LANDONI, N., 1990. La familia Mycetopodidae Gray, 1840 en La Republica Argentina. In RINGUELET, R. A. (Ed.). Fauna de água Dulce de la Republica Argentina. Buenos Aires: FECIC. vol. 16, p. 1-86.

COLLE, AC. and CALLIL, CT., 2012. Composição e estrutura da assembléia de bivalves bentonicos em lagos da planície de inundação do Cuiabá, Pantanal, Brasil. Brazilian Journal of Biology, vol. 72. In press.

EVERSOLE, AG., 1989. Clam Mariculture in North America, 3: Gametogenesis and Spawning in North American Clam Populations: Implications for Culture. Amsterdam: Elsevier Science Publishing.

FRYER, G., 1970. Biological aspects of parasitism of freshwater fishes by crustaceans and mollusks. In TAYLOR, ER. and MULLER, R. (Eds.). Aspects of Fish Parasitology. British Society for Parasitology. vol. 8, p. 103-118.

GALBRAITH, HS. and VAUGHN, CC., 2009. Temperature and food interact to influence gamete development in freshwater mussels. Hydrobiologia, vol. 636, p. 35-47. http://dx.doi.org/10.1007/ s10750-009-9933-3

GROTTA, M. and LUNETTA, JE., 1980. Ciclo sexual de Anomalocardia brasiliana (Gmelin, 1791) do Litoral do Estado da Paraíba. Revista Nordestina de Biologia, vol. 3, no.1, p. 5-55.

GUARDIA-FELIPI, P. and SILVA-SOUZA, AT., 2008. Anodontites trapesialis (LAMARCK, 1819): um bivalve parasito de peixes de água doce. Semina: Ciências Agrárias, vol. 29, no. 4, p. 895-904.

HAAG, WR. and WARREN-JUNIOR, ML., 1997. Host Fishes and Reproductive Biology of 6 Freshwater Mussel Species from the Mobile Basin, USA. Journal of the North American Benthological Society, vol. 16, no. 3, p. 576-585. http://dx.doi. org/10.2307/1468145

-, 2003. Host Fishes and Infection Strategies of Freshwater Mussels in Large Mobile Basin Streams, USA, Oxford. Journal of the North American Benthological Society, vol. 22, no. 1, p. 78-91. http://dx.doi.org/10.2307/1467979

HEARD, WH., 1975. Sexuality and other aspects of reproduction in Anodonta (Pelecypoda: Unionidae). Malacologia, vol. 15, no. 1 , p. 81-103.

HICKMAN, RW. and ILLINGWORTH, J., 1980. Condition cycle of the green-lipped mussel Perna canaliculus in New Zealand. Journal Marine Biology, vol. 60, no. 1, p. 27-38. http://dx.doi. org/10.1007/BF00395603
HOGGARTH, MA., 1992. An examination of the glochidia-host relationships reported in the literature for North American species of Unionacea (Mollusca: Bivalvia). Malacology Data Net, vol. 3, p. 1-30.

ITUARTE, CF., 1984. Aspectos biológicos de las poblaciones de Corbicula largillierti Philippi (Mollusca, Pelecypoda) en el Río de la Plata. Revista do Museo La Plata, vol. 13, no. 143, p. 231-247.

JONES, HA., SIMPSONS, RD. and HUMPHEREY, CL., 1986. The reproductive cycles and glochidia of fresh-water mussels (Bivalvia: Hyriidae) of the Macley river, Northern New South Wales, Australia. Malacologia, vol. 2, no. 1, p. 185-202.

JUNK, W., BAYLEY, PB. and SPARKS, RG.1989. The flood pulse concept in river floodplain system. Canadian Special Publication of Fisheries and Aquatic Science, vol. 106, p. 110-127.

JUNK, WJ. and CUNHA, CN. 2005. Pantanal: a large South American wetland at a crossroads. Ecological Engineering, vol. 24, p. 391-401. http://dx.doi.org/10.1016/j.ecoleng.2004.11.012

KNEELAND, SC. and RHYMER, JM., 2007. A molecular identification key for freshwater mussel glochidia encysted on naturally parasitized fish hosts in Maine. London. Journal of Molluscan Studies, vol. 73, no. 3, p. 279-282. http://dx.doi. org/10.1093/mollus/eym017

LIMA-JUNIOR, SE., CARDONE, IB. and GOITEIN, R., 2002. Determination of a method for calculation of Allometric Condition Factor of fish. Acta Scientiarum, vol. 24, no. 2, p. 397-400.

LOPES, JLC., CASANOVA, IC., FIGUEIREDO, MCG., NATHER, FC. and AVELAR, WE P., 1992. Anodontites trapesialis: a biological monitor of organochlorine pesticides. Archives of Environmental Contamination and Toxicology, vol. 23, no. 3, p. 351-354. PMid:1456780. http://dx.doi.org/10.1007/BF00216244

MANSUR, MCD., SHULTZ, C., GARCES, C. and PARES, LMM., 1987. Moluscos Bivalves de água doce: Identificação dos gêneros do Sul e Leste do Brasil. Acta Biologica Leopoldensia, no. 2, p. 181-202

MALDONADO, M., COSTA, FA., ISURZA, LJ. and BARRA, C., 1990. Aspectos biológicos de Anodontites (Anodontites) soleniformes (Mollusca-Bivalvia) en el Arroyo Chipiriri (Cochabamba-Bolivia). Acta Limnologica Brasiliensia, vol. 3, p. $847-863$

McIVOR, AL. and ALDRIDGE, DC., 2007. The Reproductive Biology of the Depressed River Mussel, Pseudanodonta Complanata (Bivalvia:Unionidae), With Implications for its Conservation. Journal of Molluscan Studies, vol. 73, p. 259-266. http://dx.doi. org/10.1093/mollus/eym023

MURPHY, G., 1942. Relationship of the freshwater mussel to trout in the Truckee River. California Fish and Game, vol. 28, p. 89-102.

OLIVEIRA, MD., HAMILTON, SK., CALHEIROS, DF., JACOBI, CM and LATINI, RO., 2010. Modeling the potential distribution of the invasive golden mussel Limnoperna fortunei in the Upper Paraguay River system using limnological variables. Brazilian Journal of Biology, vol. 70, p. 831-840. http://dx.doi.org/10.1590/ S1519-69842010000400014

ORBAN, EL., NEVIGATO, G., CASINI, IT., MARZETTI, A. and CAPRONI, R., 2002. Seasonal changes in meat content, condition index and chemical composition of mussels (Mytilus galloprovincialis) cultured in two different Italian sites. Food Chemistry, vol. 77, p. 57-65. http://dx.doi.org/10.1016/S03088146(01)00322-3 
PARKER, RS., HACKNEY, CT. and VIDRINE, MF., 1984. Ecology and reproduction strategy of a south Louisiana freshwater mussel Glebula rotundata (Lamarck) (Unionidae: Lampsilini). Freshwater Invertebrate Biology, vol. 3, p. 53-58. http://dx.doi. org/10.2307/1467094

REBELO, MF., AMARAL, MCR. and PFEIFFER, WC., 2005. Oyster condition index in Crassostrea rhizophorae (Guilding, 1828) from a heavy-metal polluted coastal lagoon. Brazilian Journal of Biology, vol. 65, no. 2, p. 345-351.

SILVA-SOUZA, AT. and EIRAS, JC., 2002. Histopathology of the Infection of Tilapia rendalli and Hypostomus regani (Osteichthyes) by lasidium larvae of Anodontites trapesialis (Mollusca, Bivalvia). Memórias Instituto Oswaldo Cruz, vol. 97, no. 3, p. 431-433. http://dx.doi.org/10.1590/S0074-02762002000300029

SILVA-SOUZA, AT., GUARDIA-FELIPI, P. and ARREBOLA, NR., 2011. Embryonic development of Anodontites trapesialis (Lamarck, 1819) (Bivalvia: Mycetopodidae). Brazilian Journal of Biology, vol. 71, p. 139-144. http://dx.doi.org/10.1590/S151969842011000100020

SMAAL, AC. and VAN STRALEN, MR., 1990. Average annual growth and condition of mussels as a function of food source. Journal Hydrobiology, vol. 195, no. 1, p. 179-188. http://dx.doi. org/10.1007/BF00026822

SMITH, DG., LANG, BK. and GORDON, ME., 2003. Gametogenetic cycle, reproductive anatomy, and larval morphology of Popenaias Popeii (Unionoida) from the black river, New Mexico. The Southwestern Naturalist, vol. 48, no. 3, p. 333-340. http://dx.doi. org/10.1894/0038-4909(2003)048\%3C0333:GCRAAL\%3E2.0.CO;2

STRAYER, DL., 2008. Freshwater Mussel Ecology: a multifactor approach to distribution and abundance. Freshwater ecological Series, University of California Press. 204 p.
TELLO-PANDURO, B., GARCÍA-VASQUEZ, Y., VIVANCO-MEDINA, M., VITERI, JD., BAÇA, JH. and TABOADA, OM., 2003. Secado de tilpaia (Oreochromis sp.), almejas (Anodontites trapesialis) y camarón gigante (Macrobrachium rosenbergii). In Proceedings of the Segundo Congreso Iberoamericano Virtual de Acuicultura, 2003. Revista Aquatic. p. 775-783. Available from: <http://www.revistaaquatic.com/civa2003/coms/listado. asp?cod=56>. Access in: 27 set. 2009

TOMAZELLI, AC., MARTINELLI, LA., AVELAR, WEA., CAMARGO, PB., FOSTIER, AH., FERRAZ, ESB., KRUG, FJ. and JÚNIOR, DS., 2003. Biomonitoring of $\mathrm{Pb}$ and $\mathrm{Cd}$ in two impacted watersheds in Souttheast Brazil, using the freashwater mussel Anodontites trapesilais (Lamarck, 1819) (Bivalvia: Mycetopodidadae) as a biological monitor. Brazilian Archives of Biology and Technology, v. 46, no. 4, p. 673-684. http://dx.doi. org/10.1590/S1516-89132003000400022

VAUGHN, CC. and HAKENKAMP, CC., 2001. The functional role of burrowing bivalves in freshwater ecosystems. Freshwater Biology, vol. 46, p. 1431-1446. http://dx.doi.org/10.1046/j.13652427.2001.00771.x

WANTZEN, MK., CUNHA, CN., JUNK, WJ., GIRARD, P., ROSSETTO, OC., PENHA, JM., COUTO, EG., BECKER, M. PRIANTE, G., TOMAS, WM., SANTOS, S., MARTA, J., DOMINGOS, I., SONODA, F., CURVO, M. and CALLIL, CT., 2008. Towards a sustainable management concept for ecosystem services of the Pantanal wetland. Ecohydrological Processes and Sustainable Floodplain Management, vol. 8, no. 2-4, p. 115-138.

YEAGER, BL. and NEVES, RJ., 1986. Reproductive cycle and fish hosts of the rabbit's foot mussel, Quadrula cylindrica strigillata (Mollusca: Unionidae), in the upper Tennessee River drainage. American Midland Naturalist, vol. 116, p. 329-340. http://dx.doi.org/10.2307/2425741 